\title{
DECONSTRUCTION OF THE CHARACTER LYDIA BENNET IN JANE AUSTEN'S PRIDE AND PREJUDICE
}

\author{
Rita Hayati \\ Universitas Pamulang \\ Dosen01163@unpam.ac.id
}

\begin{abstract}
Pride and Prejudice is one of the greatest literary work. It is a story about the Bennets daughters' love life. One of whom is Lydia Bennet, assumed as the antagonist, whose character is going to be deconstructed using Derrida theory of Deconstruction. The purpose of this research is to find out how the readers' interpretation over a character in a story may be different from what has been expected by the author. The readers, however, may attack what has been structured hierarchically once they doubt about what it is written in the text. Since family is the first to shape a child's behaviour, thus Lydia's parents as well as her four older sisters are responsible for her misbehaviour.
\end{abstract}

Keywords: Derrida's Deconstruction, Pride and Prejudice, Lydia Bennet

\section{INTRODUCTION}

When we hear or read a family named 'the Bennets', we will automatically remember a popular novel written by Jane Austen, Pride and Prejudice. It is a story about five girls whose parents are so eager to find them husbands. Living single in the twenties were used to considered miserable hence the parents would visit some matchmakers to arrange a marriage for their children. Lydia Bennet, aged 15 , is the youngest daughter of the family so her parents were not really considering to get her marriage arranged so soon, however she became the first to get married.

Lydia is depicted as a daughter with misbehaviour. She is so imprudent that people tend to be annoyed over her character. Besides, she does not care about what people think over her. She is her mother's child. Mrs. Bennet is always on her side whenever her sisters are arguing with her. Being misbehaved, she then is less favored. However the writer doesn not take a blame over the character for it is purely shaped by the condition of the family. To strengthen her opinion, the writer uses the Deconstruction Method from Derrida in helping her analyse what triggers Lydia to be so.

Related research was done by Dr. Haryatmoko in his Critical Discourse Analysis (2016). There he deconstructed a short story entitled 'Jendela Tua' by Jyut Fitra.

The story of Jendela tua was deconstructed into how the loneliness is considered another form of selfishness in seeking the social attention which cannot be achieved. This loneliness is the unaccepted feeling about the surrounding situation opposite to what is expected and thus accusing about how impertinent and ungrateful the others are.

Deconstruction does not show that all texts are meaningless, but rather that they are overflowing with multiple and often conflicting meanings. Similarly, deconstruction does not claim that concepts 
have no boundaries, but that their boundaries can be parsed in many different ways as they are inserted into new contexts of judgment. Although people use deconstructive analyses to show that particular distinctions and arguments lack normative coherence, deconstruction does not show that all legal distinctions are incoherent. Deconstructive arguments do not necessarily destroy conceptual oppositions or conceptual distinctions. Rather, they tend to show that conceptual oppositions can be reinterpreted as a form of nested opposition (Balkin 1990a). A nested opposition is an opposition in which the two terms bear a relationship of conceptual dependence or similarity as well as conceptual difference or distinction. Deconstructive analysis attempts to explore how this similarity or this difference is suppressed or overlooked. Hence deconstructive analysis often emphasizes the importance of context in judgment, and the many changes in meaning that accompany changes in contexts of judgment.

Deconstruction's emphasis on the proliferation of meanings is related to the deconstructive concept of iterability. Iterability is the capacity of signs (and texts) to be repeated in new situations and grafted onto new contexts. Derrida's aphorism "iterability alters" (Derrida 1977) means that the insertion of texts into new contexts continually produces new meanings that are both partly different from and partly similar to previous understandings. (Thus, there is a nested opposition between them.). The term "play" is sometimes used to describe the resulting instability in meaning produced by iterability.

Although deconstructive arguments show that conceptual oppositions are not fully stable, they do not and cannot show that all such oppositions can be jettisoned or abolished, for the principle of nested opposition suggests that a suppressed conceptual opposition will usually reappear in a new guise. Moreover, although all conceptual oppositions are potentially deconstructible in theory, not all are equally incoherent or unhelpful in practice. Rather, deconstructive analysis studies how the use of conceptual oppositions in legal thought has ideological effects: how their instability or fuzziness is disguised or suppressed so that they lend unwarranted plausibility to legal arguments and doctrines. Because all legal distinctions are potentially deconstructible, the question when a particular conceptual opposition or legal distinction is just or appropriate turns on pragmatic considerations. Hence, deconstructive arguments and techniques often overlap with and may even be in the service of other approaches, such as pragmatism, feminism or critical race theory.

Scope and Limitation

The research will be focus on the character Lydia Bennet. The researcher will analyse what factors trigger Lydia Bennet's misbehaviour.

\section{Problem Statement}

1. What factors trigger Lydia Bennet's misbehaviour? 
2. How is Lydia Bennet's misbehaviour deconstructed?

Benefits of Research

1. To comprehend what factors trigger Lydia Bennet's misbehaviour.

2. To comprehend how Derrida's

Deconstruction theory may help us understand Lydia Bennet's misbehaviour.

\section{METHODS}

This is a library research in which the researcher will peruse some sources supporting her data. She will start it from reading the substantial novel then underline data related to Lydia Bennet. Some supporting material related to Derrida's construction will also be perused in order to synchronize the data. In the end, the Sociology theory will also be used to study the character's background back then.

When younger, children acquire social knowledge and attitudes which may endure into adulthood and which have the potential to lead to short- and long-term psychological and physical harm to young members of minority groups. (Drukin, 1995). Children learn their attitudes toward particular ethnic groups, either by direct training or by observing and imitating their parents' verbal and non-verbal behaviour, presumably because the children are rewarded for their imitative behaviour, identify with their parents with their parents, or want to please them. (Nesdale, 2012). A child's attitude to other groups of the children depends upon his/her level development in relation to two overlapping sequenes of perceptual-cognitive development. (Aboud, 1988)

\section{Technique collecting data}

The researcher has been reading the Pride and Prejudice novel for more than ten years, however in order to conduct this research, she reread it and particularly focused on the character of Lydia. She wrote down the focal point which then by the help of Derrida's deconstruction.

Pride and Prejudice, a novel written by a famous author, Jane Austen, was published in 1813. The writer uses the novel from Wordsworth Editions first published in 1993.

\section{FINDINGS AND DISCUSSION}

\section{Chapter 1}

Mr. Bennet was so odd a mixture of quick parts, sarcastic humour, reserve, and caprice, that the experience of three-and-twenty years had been insufficient to make his wife understand his character. Her mind was less difficult to develop. She was a woman of mean understanding, little information, and uncertain temper. When she was discontented, she fancied herself nervous. The business of her life was to get her daughters married; its solace was visiting and news.

On chapter one, the readers have been described the characteristics of Mr. and Mrs. Bennet.

Children learn their attitudes toward particular ethnic groups, either by direct training or by observing and imitating their parents' verbal and non-verbal behaviour, presumably because the children are rewarded 
for their imitative behaviour, identify with their parents with their parents, or want to please them. (Nesdale, 2012)

\section{Chapter 2}

"...Lydia, my love, though you are the youngest, I dare say Mr. Bingley will dance with you at the next ball."

"Oh!" said Lydia stoutly, "I am not afraid; for though I am the youngest, I'm the tallest."

The former citation was spoken by Mrs. Bennet. She was not so sensitive about the fact that her first daughter was still single that she gave the outspoken statement over whether Lydia would have the same opportunity to be liked by Mr. Bingley, center of the attention to which the girls searched for.

Then the latter citation which clearly replied by Lydia with convidence that she could be the rival of getting a husband for she had a good appearance.

\section{Chapter 7}

The two youngest of the family, Catherine and Lydia, were particularly frequent in these attentions; their minds were more vacant than their sisters', and when nothing better offered, a walk to Meryton was necessary to amuse their morning hours and furnish conversation for the evening; and however bare of news the country in general might be, they always contrived to learn some from their aunt. At present, indeed, they were well supplied both with news and happiness by the recent arrival of a militia regiment in the neighbourhood; it was to remain the whole winter, and Meryton was the headquarters.
A child's attitude to other groups of the children depends upon his/her level development in relation to two overlapping sequenes of perceptual-cognitive development. (Aboud, 1988).

At the time, an unmarried girl must be chaperoned when going out. However, Mr. and Mrs. Bennet do not seem to mind their leaving without a chaperone.

\section{Chapter 9}

Lydia declared herself satisfied. "Oh! yes-it would be much better to wait till Jane was well, and by that time most likely Captain Carter would be at Meryton again. And when you have given your ball," she added, "I shall insist on their giving one also. I shall tell Colonel Forster it will be quite a shame if he does not."

Lydia is not a modest girl. She says what is it in her thought. It is indeed what Mrs. Bennet is despite its impertinence.

\section{Chapter 10}

"I hope," said she, as they were walking together in the shrubbery the next day, "you will give your mother-in-law a few hints, when this desirable event takes place, as to the advantage of holding her tongue; and if you can compass it, do cure the younger girls of running after officers. And, if I may mention so delicate a subject, endeavour to check that little something, bordering on conceit and impertinence, which your lady possesses."

Caroline Bingley says the abovementioned statement. It supports what is is written on the previous chapter. 


\section{Chapter 12}

Catherine and Lydia had information for them

of a different sort. Much had been done and much had been said in the regiment since the preceding Wednesday; several of the officers had dined lately with their uncle, a private had been flogged, and it had actually been hinted that Colonel Forster was going to be married.

When younger, children acquire social knowledge and attitudes which may endure into adulthood and which have the potential to lead to short- and long-term psychological and physical harm to young members of minority groups. (Drukin, 1995)

The subject about militia draws Lydia's attention so much. Her mother even support her to get married to one of the militia.

\section{Chapter 14}

Lydia was bid by her two eldest sisters to hold her tongue; but Mr. Collins, much offended, laid aside his book, and said:

"I have often observed how little young ladies are interested by books of a serious stamp, though written solely for their benefit. It amazes me, I confess; for, certainly, there can be nothing so advantageous to them as instruction. But I will no longer importune my young cousin."

When Mr. Collins, a cousin, is reading the sermons, Lydia does not seem to care and thus talks to her mother instead. Her two elder sisters even warn her to behave, however Mrs. Bennet protects her.

\section{Chapter 15}

But the attention of every lady was soon caught by a young man, whom they had never seen before, of most gentlemanlike appearance, walking with another officer on the other side of the way. The officer was the very Mr. Denny concerning whose return from London Lydia came to inquire, and he bowed as they passed. All were struck with the stranger's air, all wondered who he could be; and Kitty and Lydia, determined if possible to find out, led the way across the street, under pretense of wanting something in an opposite shop, and fortunately had just gained the pavement when the two gentlemen, turning back, had reached the same spot. Mr. Denny addressed them directly, and entreated permission to introduce his friend, $\mathrm{Mr}$. Wickham, who had returned with him the day before from town, and he was happy to say had accepted a commission in their corps.

Inspite of her sisters and Mr. Collins's company, Lydia shows no modesty to talk cheerfully with the militia. Her sisters do not even try to stop her for they consider it means no harm.

\section{Chapter 23}

Mrs. Bennet was really in a most pitiable state. The very mention of anything concerning the match threw her into an agony of ill-humour, and wherever she went she was sure of hearing it talked of. The sight of Miss Lucas was odious to her. As her successor in that house, she regarded her with jealous abhorrence. Whenever Charlotte came to see them, she concluded her to be anticipating the hour of possession; and whenever she spoke in a low voice to Mr. Collins, was convinced that they were talking of the Longbourn estate, and 
resolving to turn herself and her daughters out of the house, as soon as Mr. Bennet were dead. She complained bitterly of all this to her husband.

Mrs. Bennet detests someone to be above her family. Whenever other families have more fortune, she always has something to say as if they did not deserve the fortune.

\section{Chapter 26}

All this was acknowledged to Mrs. Gardiner; and after relating the circumstances, she thus went on: "I am now convinced, my dear aunt, that I have never been much in love; for had I really experienced that pure and elevating passion, I should at present detest his very name, and wish him all manner of evil. But my feelings are not only cordial towards him; they are even impartial towards Miss King. I cannot find out that I hate her at all, or that I am in the least unwilling to think her a very good sort of girl. There can be no love in all this. My watchfulness has been effectual; and though I certainly should be a more interesting object to all my acquaintances were I distractedly in love with him, I cannot say that I regret my comparative insignificance. Importance may sometimes be purchased too dearly. Kitty and Lydia take his defection much more to heart than I do. They are young in the ways of the world, and not yet open to the mortifying conviction that handsome young men must have something to live on as well as the plain."

Elizabeth realizes how she opposes the way Lydia thinks about a handsome man. She tries to do something to fix but their mother has more influence to Lydia's character.

\section{Chapter 29}

"That is very strange. But I suppose you had no opportunity. Your mother should have taken you to town every spring for the benefit of masters."

"My mother would have had no objection, but my father hates London."

"Has your governess left you?"

"We never had any governess."

"No governess! How was that possible? Five daughters brought up at home without a governess! I never heard of such a thing. Your mother must have been quite a slave to your education."

' Are any of your younger sisters out, Miss Bennet?"

"Yes, ma'am, all."

"All! What, all five out at once? Very odd! And you only the second. The younger ones out before the elder ones are married! Your younger sisters must be very young?"

As stated by Lady Catherine de Bourgh, some family should have a governess to teach manner to the daughters in order to get their accomplisment to fulfill society's demand over good wives. She added that the younger sisters may not attend some ball until the eldest was engaged to matrimony. In this case, Jane should be the only one to attend the ball. The companion from Elizabeth as what Mr. Bennet said as the most sensible child would not do any harm but to save the Bennets name. However that the fact that Jane was still single and that Elizabeth as the second daughter may 
attend a ball with Jane had been an excuse to Mrs. Bennet to let the other girls to attent the same ball. The only thought of Mrs. Bennet was to get her daughters married. she did not care about who would be the first to get into matrimony.

\section{Chapter 39}

"How nicely we are all crammed in," cried Lydia. "I am glad I bought my bonnet, if it is only for the fun of having another bandbox! Well, now let us be quite comfortable and snug, and talk and laugh all the way home. And in the first place, let us hear what has happened to you all since you went away. Have you seen any pleasant men? Have you had any flirting? I was in great hopes that one of you would have got a husband before you came back. Jane will be quite an old maid soon, I declare. She is almost three-andtwenty!

Lydia's only concern is the militia life. She would like to attract the soldier's attention. She thinks she is the loveliest daughter and so she will get married first while her first sister will remain old maid. She even impertinently asks her sister to flirt a man as a way to get a husband.

"Oh! Mary," said she, "I wish you had gone with us, for we had such fun! As we went along, Kitty and I drew up the blinds, and pretended there was nobody in the coach; and I should have gone so all the way, if Kitty had not been sick; and when we got to the George, I do think we behaved very handsomely, for we treated the other three with the nicest cold luncheon in the world, and if you would have gone, we would have treated you too. And then when we came away it was such fun! I thought we never should have got into the coach. I was ready to die of laughter. And then we were so merry all the way home! we talked and laughed so loud, that anybody might have heard us ten miles off!"

Lydia is lucky enough to have a foolish sister like Kitty. Kitty will follow her lead and so, they enjoy their time among the others.

\section{Chapter 41}

The rapture of Lydia on this occasion, her adoration of Mrs. Forster, the delight of Mrs. Bennet, and the mortification of Kitty, are scarcely to be described. Wholly inattentive to her sister's feelings, Lydia flew about the house in restless ecstasy, calling for everyone's congratulations, and laughing and talking with more violence than ever; whilst the luckless Kitty continued in the parlour repined at her fate in terms as unreasonable as her accent was peevish.

"I cannot see why Mrs. Forster should not ask me as well as Lydia," said she, "Though I am not her particular friend. I have just as much right to be asked as she has, and more too, for I am two years older."

Mr. Bennet saw that her whole heart was in the subject, and affectionately taking her hand said in reply:

"Do not make yourself uneasy, my love. Wherever you and Jane are known you must be respected and valued; and you will not appear to less advantage for having a couple of - or I may say, three-very silly sisters. We shall have no peace at Longbourn if Lydia 
does not go to Brighton. Let her go, then. Colonel Forster is a sensible man, and will keep her out of any real mischief; and she is luckily too poor to be an object of prey to anybody. At Brighton she will be of less importance even as a common flirt than she has been here. The officers will find women better worth their notice. Let us hope, therefore, that her being there may teach her her own insignificance. At any rate, she cannot grow many degrees worse, without authorising us to lock her up for the rest of her life."

Mr. and Mrs. Bennet do not forbid Lydia's leaving for Brighton. Elizabeth tries to warn her father of how hazardous it will be considering Lydia's bahaviour yet her father thinks Lydia should not be stopped to do something she really wants for it will make her wilder.

\section{Chapter 42}

When Lydia went away she promised to write very often and very minutely to her mother and Kitty; but her letters were always long expected, and always very short. Those to her mother contained little else than that they were just returned from the library, where such and such officers had attended them, and where she had seen such beautiful ornaments as made her quite wild; that she had a new gown, or a new parasol, which she would have described more fully, but was obliged to leave off in a violent hurry, as Mrs. Forster called her, and they were going off to the camp; and from her correspondence with her sister, there was still less to be learnt-for her letters to
Kitty, though rather longer, were much too full of lines under the words to be made public.

This chapter shows how little Lydia's attention to her family is. She cannot be blamed for her mother is always standing on her and thus she gradually becomes selfish.

\section{Chapter 47}

"MY DEAR HARRIET,

"You will laugh when you know where I am gone, and I cannot help laughing myself at your surprise to-morrow morning, as soon as I am missed. I am going to Gretna Green, and if you cannot guess with who, I shall think you a simpleton, for there is but one man in the world I love, and he is an angel. I should never be happy without him, so think it no harm to be off. You need not send them word at Longbourn of my going, if you do not like it, for it will make the surprise the greater, when I write to them and sign my name 'Lydia Wickham.' What a good joke it will be! I can hardly write for laughing. Pray make my excuses to Pratt for not keeping my engagement, and dancing with him to-night. Tell him I hope he will excuse me when he knows all; and tell him I will dance with him at the next ball we meet, with great pleasure. I shall send for my clothes when I get to Longbourn; but I wish you would tell Sally to mend a great slit in my worked muslin gown before they are packed up. Good-bye. Give my love to Colonel Forster. I hope you will drink to our good journey.

"Your affectionate friend, "LYDIA BENNET." 
Her family's permission for her going gets Lydia define that she is allowed in searching of a husband. Her elopment is not a shame for her.

\section{Chapter 48}

"You go to Brighton. I would not trust you so near it as Eastbourne for fifty pounds! No, Kitty, I have at last learnt to be cautious, and you will feel the effects of it. No officer is ever to enter into my house again, nor even to pass through the village. Balls will be absolutely prohibited, unless you stand up with one of your sisters. And you are never to stir out of doors till you can prove that you have spent ten minutes of every day in a rational manner."

Kitty, who took all these threats in a serious light, began to cry.

"Well, well," said he, "do not make yourself unhappy. If you are a good girl for the next ten years, I will take you to a review at the end of them."

After what happens to Lydia, Mr. Bennet turn strictly about tending to his daughters. Kitty becomes his most concern for she is the closest with Lydia.

\section{Chapter 49}

"My dear, dear Lydia!" she cried. "This is delightful indeed! She will be married! I shall see her again! She will be married at sixteen! My good, kind brother! I knew how it would be. I knew he would manage everything! How I long to see her! and to see dear Wickham too! But the clothes, the wedding clothes! I will write to my sister Gardiner about them directly. Lizzy, my dear, run down to your father, and ask him how much he will give her. Stay, stay, I will go myself. Ring the bell, Kitty, for Hill. I will put on my things in a moment. My dear, dear Lydia! How merry we shall be together when we meet!"

Girls, can I do anything for you in Meryton? Oh! Here comes Hill! My dear Hill, have you heard the good news? Miss Lydia is going to be married; and you shall all have a bowl of punch to make merry at her wedding."

Inspite of the elopment, Mrs. Bennet is shamelessly happy so long as it is about marriage.

\section{Chapter 51}

"Only think of its being three months," she cried, "since I went away; it seems but a fortnight I declare; and yet there have been things enough happened in the time. Good gracious! when I went away, I am sure I had no more idea of being married till I came back again! though I thought it would be very good fun if I was."

Her father lifted up his eyes. Jane was distressed. Elizabeth looked expressively at Lydia; but she, who never heard nor saw anything of which she chose to be insensible, gaily continued, "Oh! mamma, do the people hereabouts know I am married to-day? I was afraid they might not; and we overtook William Goulding in his curricle, so I was determined he should know it, and so I let down the side-glass next to him, and took off my glove, and let my hand just rest upon the window frame, so that he might see the ring, and then I bowed and smiled like anything." 
Elopement was something Lydia fail to understand. She, just like her mother, does not seem to be ashamed but shows off about her success in marrying a militia and outrunning her sisters.

The writer had analysed the same novel using Maslow's Hierarchy of Needs in which she wrote about how some girls, one of whom was Lydia Bennter, were pursuing their happiness through matrimony. With the last analysis, Lydia showed how marriage had affected her being more than her sisters, given the fact that she was the youngest.

Providing that elopment was a big issue, she failed to feel so but to consider it as vanity. We may not think this as his mistake. Again, the abovementioned explanation has stated about how Mrs. Bennet herself considered that the marriage has effaced the imprudence.

\section{CONCLUSION}

Lydia Bennet, the youngest daughter of the Bennets, one of the least characters in the Pride and Prejudice novel is merely an innocent girl from a family who has spoiled her so that she became ignorant and disdainful.

Her father, Mr. Bennet was so lenient that he let her wife to always argue over his statement. Principally, his family complied him in any situation but his characteristics which seemed to be not serious and tended to reply anything sarcastically was somehow unconsciously let them to ingore his rule. Not to mention his unwillingness to argue his wife's irritating demands. He preferred to be in the library to avoid the noise coming from his wife and daughters - except Elizabeth, his favorite daugher. The elopment was actually happened due to his central point of ignorance over Elizabeth's request not to give a clearance for Lydia to attend Mrs. Foster's invitation for a vacation.

Her mother, Mrs. Bennet was an unintelligent woman. She happened to place her family as more important than others. That is what a family member should do, but her lack of propriety had brought her act to the unacceptable thus her daughters were mostly embarrased, and her husband seemed to be ingorant over this repeatedly act of Mrs. Bennet. In addition, it was so obvious that Lydia was her favorite daughter for she was so lively like she was as a teenager.

As stated by Lady Catherene de Bourgh, some family should have a governess to teach manner to the daughters in order to get their accomplisment to fulfill society's demand over good wives. She added that the younger sisters may not attend some ball until the eldest was engaged to matrimony. In this case, Jane should be the only one to attend the ball. The companion from Elizabeth as what Mr. Bennet said as the most sensible child would not do any harm but to save the Bennets name. However that the fact that Jane was still single and that Elizabeth as the second daughter may attend a ball with Jane had been an excuse to Mrs. Bennet to let the other girls to attent the same ball. The only thought of Mrs. Bennet was to get her daughters married. she did not care about who would be the first to get into matrimony. 
Her third sister, Mary was not reliable. She only concerned about moral life without even know how to apply it.

Her fourth sister, Katherine or known as Kitty, did not act at all as an elder sister for she tended to obey whatever Lydia asked and followed every single thing Lydia did. Her role model was Lydia herself.

\section{REFERENCES}

Aboud, F. E. (1988). Children and Prejudice. Oxford: Basil Blackwell.

Austen, Jane. (1993). Pride and Prejudice. London: Wordsworth Editions.

Balkin, J.M. (1994). "Transcendental Deconstruction, Transcendent Justice," 94 Mich. L. Rev. 1133.

Brown, R. Prejudice. (1995). Its Social Psychology. Oxford: Backwell.

Derrida, Jacques. (1976). Of Grammatology. Baltimore: Johns Hopkins Univ. Press.

Durkin, K. (1995). Developmental Social Psychology - From Infancy to Old Age. Oxford: Blackwell.

Horowitz, E. L, and Horowitz, R. E. (1938). Development of Social Attitudes in Children. Sociometry. JSTOR

Guerin, Wilfred L, et al. (2005). A Handbook of Critical Approcahes to Literature (fifth edition). Oxford: Oxford University Press.
Haryatmoko. (2016). Critical Discourse Analysis. Jakarta: PT. Raja Grafindo Persada.

Kinder, D. R, \& Sears, D. O. (1981). Prejudice and Politics: Symbolic Racism versus Racial Threats to the Good Life. Journal of Politics and Social Psychology.

Nesdale, Drew. (2012). Handbook of Race, Racism, and the Developing Child. Taken from http://www.vtmh.org.au/docs/crc/drewn esdale.pdf. (July 31 2017)

Soekamto, Soerjono. (1985). Max Weber: Konsep-konsep dalam Sosiologi. Jakarta: CV. Rajawali.

Soemardjan, Selo and Soelaeman Soemardi. (1964). Setangkai Bunga Sosiologi. Jakarta: FEUI Press. 